\title{
An Analysis of Cognitive Processes in EFL Writings by Two Grade Eight Indonesian Student Writers
}

\author{
FELIKS TANS \\ ORCID No. 0000-0003-1197-2115 \\ felikstansnara@yahoo.com \\ AGUSTINUS SEMIUN \\ ORCID No. 0000-0001-5666-5245 \\ agustinussemiun@gmail.com \\ Nusa Cendana University \\ Kupang, Indonesia
}

\begin{abstract}
This research is about cognitive proceses in EFL writings by two grade VIII students of a state junior high school in Kupang, Indonesia . Its purposes are to find out: 1) cognitive processes they use in their EFL writings; and, 2) who uses those cognitive processes more completely. The data analysed were two pieces of EFL writing by the students who took part in the researchers' study on the teaching and learning of EFL writing in 2014. The whole writing activities took place in their classroom for 45 minutes in November 2014. In writing, they were allowed to use dictionaries and discuss their writings with their peers and/ or teachers. The data were analyzed based on Odell's theory (1977) on writing measurement. It is found that both student writers use such cognitive processes as focus, contrast, classification, change, pysical context, and sequence. Yet, Text 2 by Ina is slightly more complete than Text 1 by Reky. In conclusion, both students are potentially good EFL student writers and it is their teachers' main task to ensure that the students keep on writing in EFL and that their teachers actively help them improve not only their use of such cognitive processes but also EFL writing components like sentence/paragraph structure and mechanics.
\end{abstract}

Keywords: EFL writing, cognitive processes, analysis, grade VIII students, Indonesia. 


\section{INTRODUCTION}

Writing in one's mother tongue or in a second or foreign language, including English as a foreign language (EFL), is an individual process (Graves, 1975/1983; Langer \& Applebee, 1987; Jenson, 1992; Calkins, 1994; Kress, 1994; Tans, 1999; Houston, 2004; Spandel, 2004; Abas \& Aziz, 2016; Sevgi, 2016). Along the writing process, (student) writers apply certain cognitive strategies like planning and generating content (Sevgi, 2016) in addition to drafting and reviewing, rereading, repeating, rehearsing, and L1 use (Sadi \& Othman, 2012) as well as using a language to focus, contrast, change, express certain physical contexts, and to sequence (Odell, 1977). In such processes, according to Taylor and Taylor (1990: 19), what is involved is "learning, producing, comprehending, and remembering language." These indeed reflect one's writing development within a paritcular time and context. Tans (2007) uses those cognitive processes in an Indonesian tertiary student's EFL writing to analyze his writing development in a period of six months. There has been no study, however, to explore basic EFL learners' cognitive processes in EFL writing nor to compare them, particularly in Indonesian context. This is why in this article, the researchers try to explore and compare cognitive processes found in EFL writings of two grade eight students of a state junior high school in the City of Kupang, Indonesia. The question is why students' cognitive processes in EFL writing need to be explored and compared.

This article, argues that such a comparision is crucial for several reasons. First, in the context of learning to write or writing to learn in schools, understanding such processes in a student's piece of writing and seeing their differences among students is crucially important as it will help student writers to know their exact stage of writing development and, in turn, based on such knowledge, to improve their writing ability by relying on what they are good at and overcoming their writing problems. In other words, in terms of the subjects of this research, that is, upper level of primary school (that is, grade VIII) - in some cases, this level is regarded as junior high school - this study is necessary to help the students understand their own writing level: knowing what aspects of writing they are good at so they can make them better and what aspects of it that they are poor at so they can overcome them along their journeys to becoming (great) writers.

Second, such knowledge would help their teachers to appropriately treat their students along their students' writing journey. Helping the students at this level is, of course, crucial as they have in front of them a very long and challenging life in which, to a certain extent, they can count on their good level of writing 
to succeed. Through their good pieces of writings, in turn, they can successfully take part in making the world a better place to live in for all. In other words, for their teachers it is important in making themselves more effective in helping their students solve their writing problems, that is, by overcoming their students' weakneses in writing and improving their writing strengths, i.e. writing aspects that they are already good at (Cf. Piazza, 2003; Smith \& Read, 2009). This is to ensure that their brighter future as writers can be guaranteed and, through their good writing, the future of humankind can also be made better. This is logical for the end goal of any piece of writing should be for creating a better world, directly or indirectly.

Third, since writing in one language is also related to writing in another language, that is, if one is good at writing in one language, EFL writing for example, he/she can also be a good writer at another language that he/she uses, that is, Indonesian in the context of Indonesian students or those who learn to write in Indonesia. In this sense, this study is crucial as one's improved writing in his/her mother tongue can positively influence one's writing in another language (Cf. Edelsky, C. 1982; Cummins, 1979; Clark, 2008).

Fourth, since writing is also about thinking that inlvolves cognitive processes like language learning, production, comprehension, and memory (Taylor \& Taylor, 1990: 19), studying students' cognitive processes means improving their thinking ability (i.e. critical thingking, logical/abstract thinking, and creative thinking). This, of course, is important as students' good thinking ability, reflected, for example, in their writings, will, in turn, help them to succeed in their education and beyond where good writing ability is always needed in this increasingly literate world.

\section{FRAMEWORK}

Studies on cognitive processes in writing can vary based on researchers' point of view. Sadi and Othman (2012), for example, view cognitive processes in writing in relation to writing strategies applied by both poor and good undergraduate student writers. Their strategies include planning, drafting, rereading, repetition, and using L1 as well as rehearsing. On the other hand, Sevgi (2016) focuses his study on advanced-level language learners' cognitive processes in writing a paragraph, that is, how they plan and generate their writing content. In other words, what he means by cognitive processes is students' planning and ways of building up their writing contents. In that sense, Sadi and Othman (2012) and 
Sevgi (2016) study (student) writers' cognitive processes in relation to writing as a process, that is, "a series of operations leading to the solution of a problem. The process begins when a writer consciously or unconsciously starts a topic and is finished when the written piece is published (Graves, 1983: 4).

Other researchers like Odell (1977) and Tans (2007), however, focus on cognitive processes in a piece of writing as a product by (student) writers. Analyzing cognitive processes in writing as product, which is a framework of this article, is based on Odell's classic theory (1977: 111-120) on measurement of intellectual processes as a growth dimension in a person's writing. In his theory, Odell says that in a piece of writing, a writer uses certain linguistic cues that indicate his/her cognitive processes, that is, words, phrases and clauses used by a writer that reflects his/her thinking processes, namely, focusing, contrasting, classifying, changing, physical contexts, and sequencing which are described below.

A writer's focus, according to Odell, can be seen in clauses/sentences that have certain grammatical subjects. The subjects of each clause and/or sentence that a writer uses in his/her writing are, therefore, linguistic cues to his/her focus. This can be seen, for example, in such sentence as, "Indonesia is a member of ASEAN.” In that sentence, its focus is Indonesia.

Cognitive processes related to contrast, Odell adds, are reflected by a writer's use of certain linguistic cues like connectives, comparasion, negation, including negative affixes, and certain lexicon. He adds that the linguistic cues used in contrastive thinking are as follows:

Connectors:

\begin{tabular}{|c|c|c|c|c|}
\hline $\begin{array}{l}\text { or } \\
\text { but } \\
\text { instead }\end{array}$ & $\begin{array}{l}\text { nor } \\
\text { however } \\
\text { though }\end{array}$ & $\begin{array}{l}\text { else } \\
\text { nevertheless } \\
\text { although }\end{array}$ & $\begin{array}{l}\text { lest } \\
\text { on the contrary } \\
\text { in spite }\end{array}$ & $\begin{array}{l}\text { otherwise alternatively } \\
\text { on the other hand } \\
\text { despite }\end{array}$ \\
\hline
\end{tabular}

Comparative and Superlative Forms: more/most less/least -er/-est

Negatives:

no not without none nothing

Negative Affixes:

anti- im- in- ir i1- dis- -less un- non- a-

Lexicon:

Noun, verbs, adjective, and adverb forms of such words as contrast, paradox, distinction, difference and their synonyms (1977:111). 
A writer's cognitive process of classification, Odell (1977: 116) adds, can be seen in his/her use of sentences/clauses, phrases, and lexicon. In syntax, its linguistic cues are sentences whose subjects and predicative nominatives are joined by linking verbs. For phrases, their linguistic cues are for example, an example, for instance, and an instance, whereas for lexicon, its linguistic cues are forms of nouns, verbs, adjectives, and adverbs of such words as similar, resemble, and class and other words whose meanings are the same as those words (similar, resemble, and class).

Linguistic cues related to change, according to Odell (1977: 118) as follows:

1. Verb, noun, adjective, or adverb forms of the word change or a synonym for change.

2. Verb phrases which can be plausibly rewritten so as to include become (e.g. realizebecome aware).

3. Verb phrases which include begin (or a synonym) or stop (or a synonym) plus a verbal (e.g. "I began to cease from noticing...).

The next cognitive process is related to physical context, that is, a writer's use of certain nouns like names of places or concrete things like stone and soil as well as perceptive things like wind as Odell (1977: 119) says, these include common names that "refer to a geographical location (e.g. the name of a city, a geographical region, a point on a map), an object in a physical setting (e.g. a house or tree), a sensory property of a physical setting (e.g. the sound of wind in the trees)."

The last cognitive process is sequence. This, according to Odell, is divided into chronological sequence and logical sequence whose grammatical cues are as follows:

Linguisitic cues to reference to time sequence:

Adverbial elements indicating that something existed before, during, or after a moment in time.

For example:

$\begin{array}{lll}\text { then } & \text { later } & \text { previously } \\ \text { when } & \text { meanwhile } & \text { earlier } \\ \text { next } & \text { subsequently } & \text { at that moment }\end{array}$


Linguisitic cues to reference to logical sequence:

Words implying a cause-effect relationship.

For example:

because since

therefore consequently

the phrase if ... then ... (1977: 120).

\section{OBJECTIVES OF THE STUDY}

In the context of Odell's theory, this study determined to: (1) find out the cognitive processes in two grade eight students' EFL writings and (2) find out who uses those cognitive processes more completely.

\section{METHODOLOGY}

This research is a descriptive one, that is, a kind of research aiming at describing a phenomenon (Borg \& Gall, 1989; Bogdan \& Biklen, 2007). In this research, the phenomenon the writers want to describe is EFL students' cognitve processes in EFL writing. Such a description is crucial for student writers themselves and their teachers as well as other relevant parties to act accodingly based on their understanding of the cognitive processes so that the students' writing in EFL and, by implication, in other languages, can be getting better day by day.

The data were collected in November 2014 when the writers did their reserach to find out how EFL writing was taught and learned in junior high schools in the City of Kupang, West Timor, Indonesia. The subjects of the research then were 39 grade VIII students of the state junior high school in the city. The students who started learning English in July 2013 were asked to write an essay on any kind of expereince they had. They were allowed to use dictionaries and to discuss their writing with their friends and/or teachers in the process of writing their essays.

It was a sit-in classroom writing activity, that is, the students had to finish their wiriting in 45 minutes and they had to submit them before they left the class. The writers then took two pieces of writing written by two students regarded as the best two in their class by their EFL teacher. The first is Text 1 below. It is written by Reky. It consists of 155 words; three paragraphs; and, 10 lines. 


\section{Text 1: My Expereince}

By Reky (Grade: VIII)

Hello, my name is Reky. I am eleven years old. I live in Tompello street number seventeen. I want to tell you my interesting experience. It's about one year ago when graduation day.

That is on 27 July 2013, Me with: Ryan, Irga, Yud, Septi, Liam, Lia, Fecia, ako, Gyne, Tifan, and Rez. We don't patient for hear our result. They say the third champion is ... "Jemy F. Wiliam", second champion for primary is "Rea N. Ropa", and the first champion or the best graduation student for Primary is ..."Reky Erik". I'm very proud to my self because I be the best graduation student for Primary.

Thanks for hear my short story. Thanks God For everything that you have do to me. And I also gave thanks very-very much to my teacher for everything that they do to me, teach me, counselling me, and many more. This is the end of my story. Thanks.

The second is Text 2 below. It is written by Ina. Like Reky, Ina is a Grade VIII student. Her writing consists of 276 words; six paragraphs; and, 18 lines.

\section{Text 2: My Expierence \\ By Ina (Grade VIII)}

Hello my name is Ina. I was 13 years old. at the moment I want to share my unforgettable experience at the First plane.

in the school holidays in June oF 2013 and then, my Father and mother Together on vacation in surabaya, I am very happy because I can take a vacation to surabaya and especially because I was able to get on a plane at the First time.

On the departure, we headed to the air port. we checked in and boarding. we use the airline garuda Indonesia. air craft engine is turned on. I Felt a little nervous. Flight attendant explaines how to use the seat belt liFe Jacket, and way of escape in an emergency before take oFF. after the Flight attendant back in place, the aircraft ready to take oFF.

By the time the Plane took oFF, I was very aFraid. My legs Trembled, because The air Craft was faster than cars. But my Fears were relieved with a view From the Plane is so amazing.

When the Plane was airborne and the seatbelt sign lights had been turned oFF, the Flight attendant tells Passangers how to use the entertainment Facilities such as watching movie on The Plane, listening music, reading magazines, and served food and drinks For us to enjoy. 
Not felt, already 2 hours we were on the Plane. I really enjoyed The atmosphere, I watch movie, look at the view From The Plane and it was time the Plane landed. the same Feeling I Felt back the same as during Take oFF that knee trembling on the Plane. It all is an unfogettable experience for me.

Before typing the essays, the writer asked the students for punctuation and spelling confirmation on their handwriting so that the typed version of each essay/writing is the same as its original essay, that is, the hand-written one. These two pieces of EFL writing were then analyzed based on Odell's cognitive process theory (1977) described before. For confidential purposes, the students' names have been changed; so do the proper names of the students mentioned in both texts.

\section{RESULTS AND DISCUSSION}

After analyzing both texts, namely, Text 1 by Reky and Text 2 by Ina, based on Odell's (1977) writing measurement theory, it is found that both texts contain several cognitive processes, namely, focus, contrast, classification, change, physical context, and sequence. How the cognitive processes are used in both texts by both student writers is described below. A comparison of cogntive processes used by both student writers is also presented.

\section{Focus}

Both Reky in Text 1 and Ina in Text 2 use this kind of cognitive process, that is, focus. The linguistic cues that indicate their focuses are grammatical subjects of each clause/sentence in their texts. Eky uses 16 grammatical subjects as in, "Hello, my name is Reky" (Line 1) and "They say the third champion is ... 'Jeremy F. William'...” (Lines 4-5). In both examples, their grammatical subjects are my name, they, and the third champion.

In Text 2, Ina has 31 grammatical subjects as in, "Hello my name is Ina (Line 1), "air craft engine is turned on" (Line 8), and "after the Flight attendant back in place, the aircraft ready to take oFF" (Lines 9-10). In the examples, the grammatical subjects are my name, air craft engine, the Flight attendant, and the aircraft successively.

The data of both texts show that Text 2 by Ina has more focusses (grammatical subjects) that those of Text 1 by Eky, that is, 31 compared to 16. This leads us to conclude that Ina is more focused that Eky in EFL writing. 


\section{Contrast}

This kind of cognitive process is divided into three sub-categories, namely, connectors, comparative/superlative forms, negative forms, negative affixes, and lexicon showing "contfrast, difference, and their synonyms." These are described below.

\section{Connectors}

Text 1 by Eky shows no contrastive thinking using certain connectors. Ina in Text 2, however, perfectly uses the connector but as in, "My legs Trembled, because The air Craft was faster than cars. But my Fears were relieved with a view From the Plane is so amazing" (Lines 11-12).

\section{Comparative/Superlative Forms}

Reky in Text 1 uses such grammatical cues as "the first," "second," "the third," and "the best" as in the following sentences (the linguistic cues are italicised):

They say the third champion is ... "Jemy F. Wiliam", second champion for primary is "Rea N. Ropa", and the first champion or the best graduation student for Primary is ..."Reky Erik". I'm very proud to my self because I be the best graduation student for Primary (Lines 4-7).

In addition, he also uses the terms "many more" as in, "And I also gave thanks very-very much to my teacher for everything that they do to me, teach me, counselling me, and many more" (Lines 8-10).

\section{Negative Forms}

In Text 1, Reky uses a negative form as in, "We don't patient for hear our result" (Line 4). Whereas Ina in Text 2 also uses one negative form as in, "Not felt, already 2 hours we were on the Plane" (Line 16).

\section{Negative Affixes}

Reky in Text 1 does not use any negative affix to indicate contrast. Yet, Ina in Text 2 uses the negative affix un- as in, "at the moment I want to share my unforgettable experience at the First plane" (Lines 1-2) and in, "It all is an unfogettable experience For me" (Lines 18-19). 


\section{Lexicon}

As stated before, linguistic cues for contrast lexicon are "noun, verb, adjective, and adverb forms of such words as contrast, paradox, distinction, difference and their synonyms" (1977:111). In that sense, Reky in Text 1 uses the term my interesting experience as in, "I want to tell you my interesting experience" (Line 2 ) and the first champion or the best graduation student as in, "... and the first champion or the best graduation student for Primary is ..."Reky Erik" (Lines 5-6). We believe that the terms my interesting experience and the first champion or the best graduation student refer to something which is "different" and/or "distinctive."

In Text 2, Ina uses such words as unforgettable as in, "at the moment I want to share my unforgettable experience at the First plane" (Lines 1-2). She also uses the words trembled and trembling as in, "My legs Trembled, because The air Craft was faster than cars" (Lines 11-12) and "the same Feeling I Felt back the same as during Take oFF that knee trembling, on the Plane" (Lines 18-19). We see these three words, namely, unforgettable, trembled, and trembling as adjective forms of the linguistic cue difference or contrast itself.

The researchers conclude that both Reky and Ina successfully use contrast cognitive process in their EFL writing. However, when it comes down to its sub-categories, namely, connectors, comparative/superlative forms, negative forms, negative affixes, and lexicon, Ina is better than Reky. Reky fails to use, for example, contrast connectors and negative affixes to indicate contrast itself.

\section{Classification}

This kind of cognitive process is divided into three sub-categories, that is, syntax, uses of phrases, and lexicon. These will be described below.

\section{Syntax}

Linguistic cue that indicates syntax as a part of classification cognitive process is the use of lingking verbs to connect subjects and their predicate nominatives. In that sense, Text 1 by Reky has nine linking verbs, that is, is used seven times and am twice as in, "Hello, my name is Reky," (Line 1) and "I'm very proud to my self because I be the best graduation student for Primary" (Lines 6-7). In Text 2, Ina uses 13 linking verbs, namely: is four times, was six times, am once, and were twice as in, "Hello my name is Ina" (Line 1), "I was 13 years old" (Line 1), "I am very happy," and "But my Fears were relieved ..." (Line 11).

The data also show that Ina has more various syntaxes that those of Reky, that is, seven compared to 13 which are almost doubled. In addition, Ina also 
uses more various linking verbs with different tenses (present and past forms) compared to Reky who simply used is and am without a past form. It is, therefore, logical to conclude that Ina is better than Reky in terms of using this kind of cognitive processes, that is, syntax as a part of classification.

\section{Phrasal Construction}

In relation to this kind of cognitive process, both student writers do not literally use such phrases as for example, an example, for instance and an instance which are linguistic cues for this cognitive process. However, both use certain phrases that indirectly indicate that they give some examples in their essays. Reky in Text 1, for example, builds up the the following sentences:

- That is on 27 July 2013, Me with: Ryan, Irga, Yud, Septi, Liam, Lia, Fecia, ako, Gyne, Tifan, and Rez. We don't patient for hear our result (Lines 3-4).

- And I also gave thanks very-very much to my teacher for everything that they do to me, teach me, counselling me, and many more (Lines 9-10).

The researchers believe that the italicized sentences/clauses/phrases are regarded as examples of what Reky has written in the previous or the following part of the sentences/clauses/phrases. In the first example, for instance, Reky uses the pronoun we in which "Me with: Ryan, Irga, Yud, Septi, Liam, Lia, Fecia, ako, Gyne, Tifan, and Rez"are examples.

Ina in Text 2 does not also literally use such words as for example, for instance, an example, and an instance, but she uses the phrase such as which is the same as an example/instance as in "... the Flight attendant tells Passangers how to use the entertainment Facilities such as watching movie on The Plane, listening music, reading magazines, and served food and drinks For us to enjoy" (Lines 13-15). She also gives some examples of enjoying her flight as in, "I really enjoyed The atmosphere, I watch movie, look at the view From The Plane ..." (Lines 16-17). In this sense, it is evident that Ina uses this "example/instance" phrase better than Eky in their EFL writing.

\section{Lexicon}

The linguistic cues for classifying lexicon as previously stated are "noun, verb, adjective, and adverb forms of such words as similar, resemble, and class and their synonyms (Odell, 1977:111). Reky in Text 1, however, does not use "exactly" the lexicon as such. Yet, he uses more or less similar lexicons indicating certain 
class of people like champion (Lines 4-5), student (Line 6), and teacher (Line 9).

Ina, however, uses the word same twice in Tex 2 whose synonym is similar, a word indicating classification cognitive process as in, "the same Feeling I Felt back the same as during Take oFF that knee trembling on the Plane," (Line 18-19). In addition, she also uses certain words indicationg a particular class/group of people in a society like father (Line 3) and mother (Line 3).

\section{Change}

As stated before, change as a kind of cognitve process in writing, according to Odell (1977: 118), has three components, namely: 1) verbs, nouns, adjectives, or adverbs related to change or its synonym; 2) verb phrases whose synonyms include the verb become (e.g. realize-become aware); and, 3) verb phrases including the verb begin orits synonym and the verb stop and its synonym plus its infinitives. In that sense, Reky in Text 1 uses be as in, "I'm very proud to my self because I be the best graduation student for Primary" (Line 7) and end as in, "This is the end of my story" (Line 10). In the context of Reky's writing, both be and end show change as a cognitive process.

On the other hand, Ina uses verbs like take, get on, turned on, felt, (be) ready, trembled, relieved, turned off and trembling to show her changing cognitive processes as in the following sentences (the grammatical cues are in italic forms):

1. ... because I can take a vacation ... because I was able to get on a plane ... (Lines 4-5).

2. air craft engine is turned on (Line 8)

3. I Felt a little nervous (Line 8).

4. after the Flight attendant back in place, the aircraft ready to take oFF (Lines 9-10).

5. My legs Trembled, because The air Craft was faster than cars (Lines 11-12).

6. But my Fears were relieved with a viewFrom the Plane is so amazing (Line 12).

7. when ... the seatbelt sign lights had been turned oFF ... (Line 13)

8. the same Feeling I Felt ... that knee trembling on the Plane (Lines 18-19).

In comparison, it is believed that Text 2 by Ina is richer than Text 1 by Reky in using changing cognitive processes. This is understandable as Text 2 is much longer than Text 1 , a fact that makes it possible to include such cognitive processes as change. 


\section{Physical Context}

This cognitive process is divided into three parts, namely: geographical locations, physical setting object, and a sensory property. Yet, in his Text 1 writing, Reky simply mentions one geographical location, that is, Tompello street number seventeen (Line 1). In addition, he also mentions another object of a physical setting, that is, for primary (Lines 6 and 7) which is supposed to be a primary school.

On the other hand, Ina in Text 2 uses such geographical locations as insurabaya (Line 4), to surabaya (Line 4), and the air port (Line 6). She also uses physical setting objects like at the First plane (Line 2), a plane (Line 5), the airline garuda Indonesia (Line 7), air craft engine (Line 8), in place (Line 10), the aircraft (Line 10), the plane (Lines 11/13), air Craft (Line 11), cars (Line 12), entertainment Facilities (Line 14), on the Plane (Lines 14/15/16/18-19), and From the Plane (Lines 12/17). In addition, she also uses some sensory properties like althe view (Lines 12/17), sign lights (Line 13), movie (Lines 14/17), magazines (Line 15), and The atmosphere (Line 16).

In comparision, Ina uses more physical contexts than Reky does. She also uses them more completely, that is, she uses some geographical locations, some objects of physical settings, and some sensory properties compared to Reky who uses one geographical location and one object of a physical setting, but not a sensory property. This means that Ina is better than Reky in using this kind of cognitive process in EFL writing.

\section{Sequence}

As it has been stated before, this cognitive process involves chronological or time sequence and logical sequence or cause-effect relationship among/between the writers' ideas expressed in their EFL writings. These are described below.

\section{Chronological/Time Sequence}

In Text 1, Reky uses such grammatical cues as first, second, and third to indicate time sequence as in, "They say the third champion is ... "Jemy F. Wiliam", second champion for primary is "Rea N. Ropa", and the first champion or the best graduation student for Primary is ..."Reky Erik" (Lines 4-6). In some cases, Reky does not explicitly use certain grammatical cues to express a time order, yet his sentence shows that a time order is used as in, "And I also gave thanks veryvery much to my teacher for everything that they do to me, teach me, counselling me, and many more" (Lines 8-10). In this kind of time order, Reky states things 
one after another which is indeed a chronological order.

In Text 2, Ina also uses some kinds of time order, that is, she uses such grammatical cues as first (Line 2), at the First time (Line 5), before (Line 9), after (Line 9), by the time (Line 11), and when (Line 13). Like Reky, she does not explicitly uses certain grammatical cues to indicate her time sequence, but she indeed writes her ideas in successive order as in, "On the departure, we headed to the air port. we checked in and boarding" (Lines 6-7). In this, what she wants to express is that they first went to the airport, then checked in, and finally went on board.

\section{Logical Sequence}

In building up this kind of sequence, Reky uses such grammatical cues as because as in, "I'm very proud to my self because I be the best graduation student for Primary" (Lines 6-7). In addition, he also uses the grammatical cue for to express his reasons as in, "Thanks for hear my short story. Thanks God For everything that you have do to me. And I also gave thanks very-very much to my teacher for everything that they do to me, teach me, counselling me, and many more" (Lines 8-10).

In Text 2, Ina also uses because to show her logical sequence as in:

1. I am very happy because I can take a vacation to surabaya and especially because I was able to get on a plane at the First time" (Lines 4-5).

2. My legs Trembled, because The air Craft was faster than cars (Lines 10-11).

In some cases, she does not explicitly use the grammatical cue becuase, yet her sentence shows that she really gives some arguments for something as in, "I really enjoyed The atmosphere, I watch movie, look at the view From The Plane and it was time the Plane landed" (Lines 16-18). In such a sentence, she mentions some reasons why she enjoys her flight, that is, because she watches a movie and looks at the amazing view outside her plane along her flight.

In comparison, Reky and Ina seem to have more or less similar competences in building up this kind of cognitive process, that is, chronological and logical sequences. Both uses them with a relatively similar level of richness and variety of ideas linked chronologically or logically. 


\section{CONCLUSIONS}

To conlude this article, it is important that that the researchers restate some major points here. First, both Reky and Ina who are at the same level of their formal education, i.e. grade VIII of junior high school, have been similarly successful in using six kinds of cognitve processes in a their EFL writing, namely, focus, contrast, classification, change, physical setting, and sequence.

Second, in general, Ina has been more competent in using those cognitive processes in her EFL writing compared to Reky. This is understandable as Ina has a much longer piece of writing than that of Reky, that is, her writing has 276 words, 18 lines, and six paragraphs compared to Riky's 155 words, 10 lines, and three paragraphs.

Third, since a piece writing of writing, according to Dunbar et al. (1990: 6), contains four major components, namely, "content (what to say), logical organization, appropriate word choice, sentence and paragraph structure, and mechanical correctness (standard grammar, spelling, punctuation)," it is important to conclude here that both pieces of writings, that is, Text 1 by Reky and Text 2 by Ina, are strong in terms of their content, word choice, and logical organization, yet their sentence and paragraph structure and mechanical correctness are pretty weak. Overall, however, they are still viewed as good pieces of writing within the contexts of the student writers who have not only learned English in just 1,5 years but also learned it within a foreign context, that is, an environment with a very few exposure to English.

Finally, despite their weaknesses in relation to their relatively poor use of standard grammar, spelling and punctuation, both student writers, i.e. Reky and Ina, are indeed potentially good student writers. It is predicted that they can significantly develop their cognitive processes in EFL writing and improve their writing quality in general, particularly their ability to better their "sentence and paragraph structure" and "mechanical correctness (standard grammar, spelling, and punctuation)," if they keep writing regularly and if, of course, their EFL teachers are active to help them improve their EFL writing.

\section{RECOMMENDATIONS}

Based on the findings of this research, the researchers would like to suggest the following ideas:

1. There is a need for further research on this issue to ensure a far better 
understanding of EFL student writers' cognitive processes within the contexts of their EFL writing. Understanding such cognitive processes based on just a couple of writing as done in this research seems to be insufficient despite the fact that it has helped them to have a clear look on the students' cognitive processes in EFL writing and, therefore, based on such understanding, to do their best to improve our students' EFL writing.

2. Since the students are potentially good student writers, EFL teachers should always encourage their students to write regularly, to frequently edit/ revise their students' writings, and publish their students' writings in school wall magazines, the Internet blogs, or anywhere so that their writings can be made public. This is important as writers usually do their best when they know that their writing is to be published.

3. One's writing competence in a language can positively influence his/her writing competence in another language, it is also a good idea that EFL teachers encourage their students to write not only in English but also in other languages that the students can use relatively well. In the context of Indonesia, this simply means that EFL teachers in Indonesia should also encourage their students to write and publish their writings in Indonesian. This is important since cognitive processes discussed in this study can also be well nurtured and natured in any language that student writers can use.

\section{LITERATURE CITED}

Abas, I.H. \& Aziz, N.H.A. (2016). "Indonesian EFL students' perspective on writing process: A pilot study.” Advances in Language and Literary Studies, Vol. 7(3), June, pp. 21-27.

Bogdan, R.C. \& Biklen, S.K. (2007). Qualitative research for education: An introduction to theories and methods. Boston: Pearson Education.

Borg, W.R. \& Gall, M.D. (1989). Educational research: An introduction. New York: Longman.

Calkins, L.M.C. (1994). The art of teaching writing. Toronto: Irwin Publishing.

Clark, I.L. (2008). Concepts in composition: Theory and practice in the teaching of writing. New Jersey: Taylor and Francis. 
Cummins, J. (1979). "Linguistic interdependence and the educational development of bilingual children." Review off Educational Research, 49(2), pp.222-251.

Dunbar, G., Dunbar, C., \& Rorabacher, L.E. (1991). Assignments in expositions. New York: HarperCollins Publishers.

Edelsky, C. (1982). "Writing in a bilingual program: The relation of L1 and L2 texts.” TESOL Quarterly, 16(2), June, pp. 211-228.

Garves, D. (1975). "An examination of the writing processes of seven year old children." Research in the teaching of english, 9(3), 1975, pp. 227241.

Graves, D. (1983). Writing: Teachers and Children at Work. London: Heinemann Educational Books.

Houston, G. (2004). How writing works: Imposing organizational structure within the writing process. New York: Pearson.

Jenson, R.M. (1992). "Can growth in writing be accelerated? An assessment of regular and accelerated college comparision course." Research in the teaching teaching of english, 26(2), pp. 194-211.

Kress, G. (1994). Learningto write. London: Routledge.

Langer, J.A. \& Applebee, A.N. (1987). how writing shapes thinking: A study of teaching and learning. Urbana, Il.: National Council of Teachers of English.

Odell, L. (1977). "Measuring changes in intellectual processes as one dimension of growth in writing." In C. R. Cooper and L. Odell (Eds.), Evaluating writing: Describing, measuring, judging. New York: National Council of Teachers of English, pp. 139-154. 
Piazza, C.L. (2003). Journeys: The teaching of awriting in elementary classrooms. New Jersey: Merill Prentice Hall.

Sadi, F. F. \& Othman, J. (2012). "An investigation into writing strategies of iranian EFL undergraduate learners." World applied sciences journal, Vol. 18(8), pp. 1148-1157.

Sevgi, E. (2016). "A comparison of the cognitive processes involved in L2 learners' writing process when they are composing in english and in their L1.” Procedia-social and behavioral sciences 232: International conference on teaching and learning english as an additional language, GlobELT, 14-17 April, Antalya, Turkey, pp. 346-353. downloaded from www.sceincedirect.com. on October 1, 2016.

Spandel, V. (2004). Creating young writers: Using the six traits to enrich writing process in primary classrooms. New York: Pearson.

Smith, J. A. \& Read, S. (2009). Early literacy instruction: Teaching reading and writing in today's primary grades. New York: Pearson.

Tans, F. (1999). EFL writing of indonesian grade 11 students: An iquiry into becoming a writer. Unpublished Ph.D. Thesis. Graduate School of Education, La Trobe University, Melbourne, Australia.

Tans, F. (2007). "Writing in EFL: An analysis of developing cognitive processes." Jurnal Ilmu Pendidikan [Educational Science Jornal], Volume 14(3), October, pp. 166-174.

Taylor, I. \& Taylor, M.M. (1990). Psycholinguistics: Learning and using language. Toronto: Prentice-Hall International. 